\title{
Kajian Dampak Iklim Ekstrim Curah Hujan Tinggi (La-Nina) Pada Jeruk Siam (Citrus Nobilis var. Microcarpa) Di Kabupaten Banyuwangi, Jember dan Lumajang
}

\author{
DOI 10.18196/pt.2014.023.49-55 \\ Hasim Ashari*, Zainuri Hanif, Arry Supriyanto \\ Balai Penelitian Jeruk dan Buah Subtropika, Jl. Raya Tlekung No.1 Junrejo Kota Batu 65301 \\ ${ }^{*}$ Corresponding author,e-mail: hasimmuda@gmail.com
}

\begin{abstract}
ABSTRAK
Sekitar 80\% jeruk di Indonesia adalah jeruk siam (Citrus nobilis var. Microcarpa). Tanaman jeruk ini dapat tumbuh dan diusahakan di dataran rendah hingga dataran tinggi (0 sampai 1500 mdpl), namun optimal dibawah 1000 mdpl.Perubahan Iklim yang ekstrim merupakan salah satu faktor yang mempengaruhipertumbuhan dan produktivitas tanaman jeruk. Jeruk siam memerlukan 6-9 bulan basah (musim hujan) dan 3-6 bulan kering (kemarau) serta perlu air yang cukup terutama di bulan Juli-Agustus (musim kemarau). Tujuan pengkajian ini untuk mengetahui pengaruh perubahan Iklim yang ekstrim dengan curah hujan tinggi (la nina) terhadap fenologi (pembungaan dan pembuahan), produktivitas dan kualitas buah jeruk siam di Banyuwangi, Jember dan Lumajang. Metode pengkajian dengan observasi di sentrajeruk dengan umur tanaman 5 sampai 12 tahun dari 2005 sampai agustus 2011. Hasil menunjukkan curah hujan tinggiterjadi sepanjang tahun 2010 (musim kemarau tidak terjadi), terjadi kekacauan fenologi yang sebelumnya tanaman jeruk berbunga 1 sampai 3 kali setahun menjadi 4 sampai 6 kali setahun namun bunga ini tidak menjadi buah (terjadi kerontokan pentil buah/jundrop) dan berakibat kegagalan panen jeruk pada 2010 dan 2011. Produktivitas menurun drastis hingga tinggal 25-40\% (5-10 ton/ha yang sebelumnya 20-30 ton/ha) dengan kualitas (warna, rasa dan total total padatan terlarut) menurun.Selain itu, kebun jeruk yang menerapkan sistem PTKJS (pengelolaan terpadu kebun jeruk sehat) hasil pendampingan Balitjestro lebih berhasil mensiasati perubahan iklim ekstrim yaitu panen 10-12 ton/ha. Didapatkan potensi baru yang baik untuk budidaya jeruk siam yaitu lahan kering/tegalan dan tanah berpasir yang semula jeruk ditanam di lahan sawah. Kata kunci : Jeruk siam, curah hujan, fenologi, produktivitas, kualitas
\end{abstract}

\begin{abstract}
Tangerine (Citrus nobilis var. microcarpa) is most widely cultivated Citrus in Indonesia, it's around 80\% of all population of Citrus. Citrus can growth and cultivated in low land or upland (0-1500 m above sea level). Indonesia has extreme climate change (La Nina) in 2009 and 2010. Extreme climate change is one of the factors that affect the growth and productivity of citrus both in quality and quantity. Tangerine require 6-9 months of wet season and 36 months of dry season, although need enough water in dry season. This research aims to study the effect of extreme climate change with high rainfall on phenology, productivity and quality of Tangerine in Banyuwangi, Jember and Lumajang. This Research was conducted at Tangerine center from 2005 until 2011 using observation method, the tangerine that use was from 5 years after planted until 12 years after planted. The Result showed that high precipitation occurred in 2010 (without dry season) affect the phenology cycle from 1-3 times in a year until 4-6 times in a year, but not become a fruit due high flower drop. It's cause a decrease in Productivity form 20-30 ton/h until 5-10 ton/h and also a decrease in quality (color, flavor and total dissolved solid). The result also showed that PITKS system (Integrated Management for Healthy Tangerine) can prevent a decrease in Tangerine Productivity (10-12 ton/h). This Research also obtained that dry land and sandy land has potential for cultivation of tangerine that originally grown in paddy field

Keywords :Tangerine, Precipitation, Phenology, Productivity, Quality
\end{abstract}

\section{PENDAHULUAN}

Indonesia dikenal memiliki banyak varietas lokasi. Walaupun demikian, pertanaman jeruk jeruk komersial yang sudah dikenal konsumen di Indonesia masih didominasi $80 \%$ oleh jeruk dalam negeri diantaranya jeruk Siam Pontianak, Siam dikarenakan produktivitasnya yang tinggi. Siam Medan, Siam Sambas, Keprok SoE, Batu Jeruk siam dapat tumbuh dan diusahakan petani 55 dan lainnya yang biasanya sangat spesifik di dataran rendah hingga dataran tinggi dengan 
varietas yang berbeda dan dapat dikonsumsi oleh masyarakat berpendapatan rendah hingga berpenghasilan tinggi. Sebagian besar buah jeruk yang dihasilkan dari seluruh sentra produksi diperdagangkan dan dikonsumsi dalam bentuk segar.

Kabupaten Banyuwangi, Jember dan Lumajang merupakan sentra produksi terbesar jeruk siam di jawa dengan luas lahan total 7500 ha (Hari, 2004). Hal ini dikarenakan kondisi tanahnya sangat cocok untuk budidaya jeruk terutama siam. Pertumbuhan tanaman jeruk siam dan mutunya selain dipengaruhi oleh kualitas bibit, tanah juga dipengaruhi oleh persyaratan tumbuhnya diantaranya iklim. Persyaratan tumbuh iklim, tanaman jeruk memerlukan 6-9 bulan basah (musim hujan), curah hujan 1000-2000 mm/tahun merata sepanjang tahun, perlu air yang cukup terutama di bulan Juli-Agustus. Temperatur optimal yang dibutuhkan antara $25-30{ }^{\circ} \mathrm{C}$ dengan kelembaban optimum sekitar 70-80\%. Kecepatan angin tidak lebih dari 40\% (karena bila lebih dari $40 \%$ akan merontokkan bunga dan buah). Jeruk memerlukan sinar matahari langsung (tidak menyukai tempat yang terlindung dari sinar matahari). Jenis tanah yang cocok adalah andosol dan latosol dengan derajat keasaman tanah (pH tanah) 5,5-6,5 dengan kandungan garam 10\%. Kedalaman air tanah 150-200 cm dibawah permukaan tanah. Pada musim kemarau kedalaman air $150 \mathrm{~cm}$ dan pada musim hujan $50 \mathrm{~cm}$. Ketinggian, jeruk dapat tumbuh pada ketinggian 0-1.200 mdpl.

Penyimpangan iklim ekstrim terhadap pertumbuhan agronomis, produktivitas dan kualitas jeruk sejak sepuluh tahun terakhir berdampak cukup serius terhadap: pertama, perubahan fenologi pembungaan tanaman dari annual menjadi pluri-annual yang berimplikasi pada produktivitas jeruk. Kedua, perubahan dinamika populasi dan meningkatnya potensi outbreak organisme pengganggu tanaman (OPT). Kondisi ini menjustifikasi pentingnya pengkajian dan penyusunan strategi untuk meminimumkan resiko kegagalan dan mengoptimumkan pengaruh dampak positif perubahan iklim ekstrim terhadap produktivitas dan kualitas jeruk siam.

\section{BAHAN DAN METODE}

Pengkajian dilaksanakan di Kabupaten Banyuwangi, Jember dan Lumajang yang merupakan sentra produksi terbesar jeruk siam (siam Sambas) di Jawa dengan luas lahan total 7500 ha. Metode pengkajian dengan olahan data sekunder dan survey lapang dengan responden petani jeruk, pegawai penyuluh lapang tiap daerah berdasarkan simple random sampling dengan umur tanaman jeruk 5 sampai 12 tahun. Analisis data kualitatif dilakukan sesuai kebutuhan dan penjelasan responden yang dilengkapi dengan hasil pengamatan dilapang. Waktu pengkajian 2005 sampai Agustus 2011.

\section{HASIL DAN PEMBAHASAN}

Perubahan iklim dapat dikelompokkan menjadi 4 (empat) fenomena (Sri Puji, 2009) yaitu :Meningkatnya temperatur udara;Meningkatnya curah hujan;Kenaikan muka air laut (sea level rise);Meningkatnya intensitas kejadian ekstrim yang di antaranya adalah :

- Meningkatnya intensitas curah hujan pada musim basah (extreme rainfall)

- Meningkatnya frekuensi dan intensitas banjir (extreme flood)

- Berkurangnya curah hujan dan debit sungai pada musim kemarau serta bertambah 


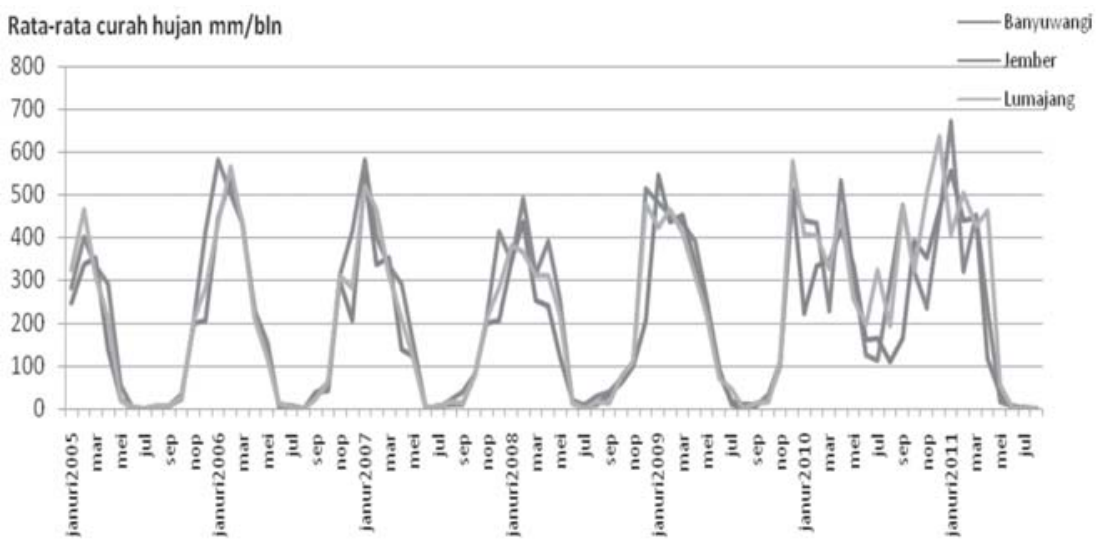

Gambar 1. Rekaman Curah Hujan di Kabupaten Banyuwangi, Jember dan Lumajang mulai Januari 2005 sampai Agustus 2011

panjangnya periode musim kering (drought)

- Meningkatnya temperatur yang diikuti gelombang panas (head waves)

- Menurunnya kualitas air pada musim kemarau

- Meningkatnya intensitas dan frekuensi badai (tropical cyclone)

- Meningkatnya tinggi gelombang dan abrasi pantai, dan

- Meningkatnya intrusi air laut.

Dari keempat kelompok tersebut yang paling berperan pada tanaman jeruk adalah pengaruh curah hujan yang ekstrim

Perubahan Iklim Curah Hujan/Ketersediaan Air Jumlah curah hujan dan distribusinya sangat menentukan ketersediaan air bagi tanaman jeruk, karena air berfungsi dalam proses pengisian sel tanaman/buah, pelarut zat kimia/ padat yang diperlukan oleh tanaman dan sebagai pengendali suhu tanaman. Berikut ini rekaman curah hujan mulai tahun 2005 sampai Agustus 2011.

Berdasarkan grafik curah hujan pada ketinggian tempat lebih dari 50 sampai $400 \mathrm{~m}$ diatas permukaan laut: curah hujan tertinggi mulai tahun 2005 sampai Agustus 2011 pada periode normal (frekuensi tidak kurang dari $25 \%$ dan tidak lebih dari $75 \%$ ) terjadi pada bulan Januari antara $431-583,5 \mathrm{~mm}$.

Sedangkan curah hujan terendah pada periode normal terjadi pada bulan Juni, Juli dan Agustus antara 0-162 mm yang disebut musim kemarau. Rata-rata curah hujan tahunan, curah hujan periode normal berkisar antara 2.783,6 - 3.684 $\mathrm{mm}$. Periode basah ditandai dengan frekuensi 0\% untuk peluang tidak terjadi hujan mulai Desember sampai Maret. Sedangkan hujan sering tidak terjadi pada bulan Juni sampai dengan September dengan frekuensi berkisar antara $22-28 \%$.

Pada tahun 2010 terjadi musim hujan terus menerus. Pada Juni, Juli dan Agustus yang biasanya tidak terjadi hujan ternyata hujan terus-menerus dengan jumlah terkecil $100 \mathrm{~mm}$. Bureau of Meteorology Australia (2010) menyatakan bahwa curah hujan yang tinggi sepanjang tahun (El Nino) dikarenakan terjadi perubahan iklim global akibat mencairnya es di kutub karena peningkatan suhu udara dibumi. 


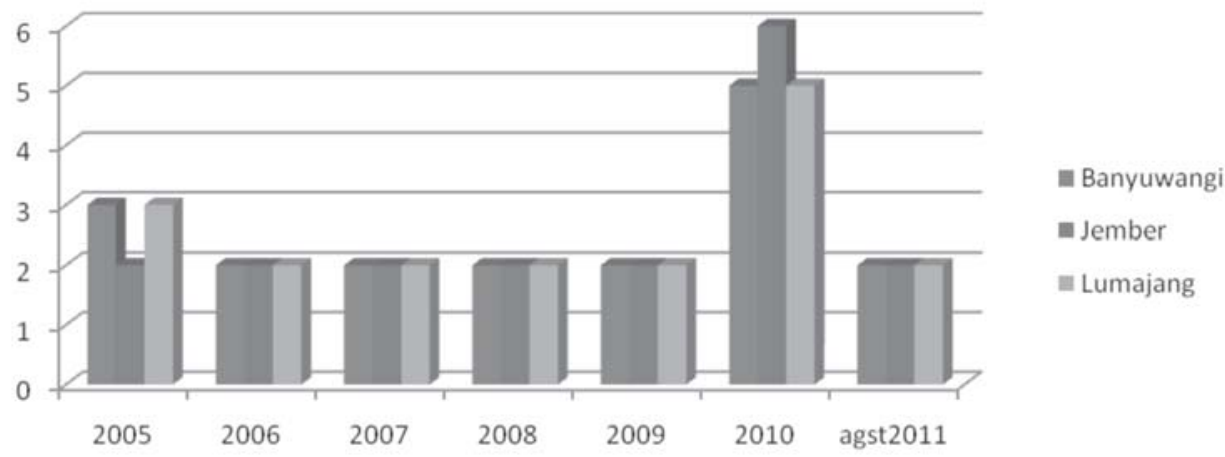

Gambar 2. Frekuensi Pembungaan Jeruk (fenologi) tiap Tahun selama 2005 sampai Agustus 2011

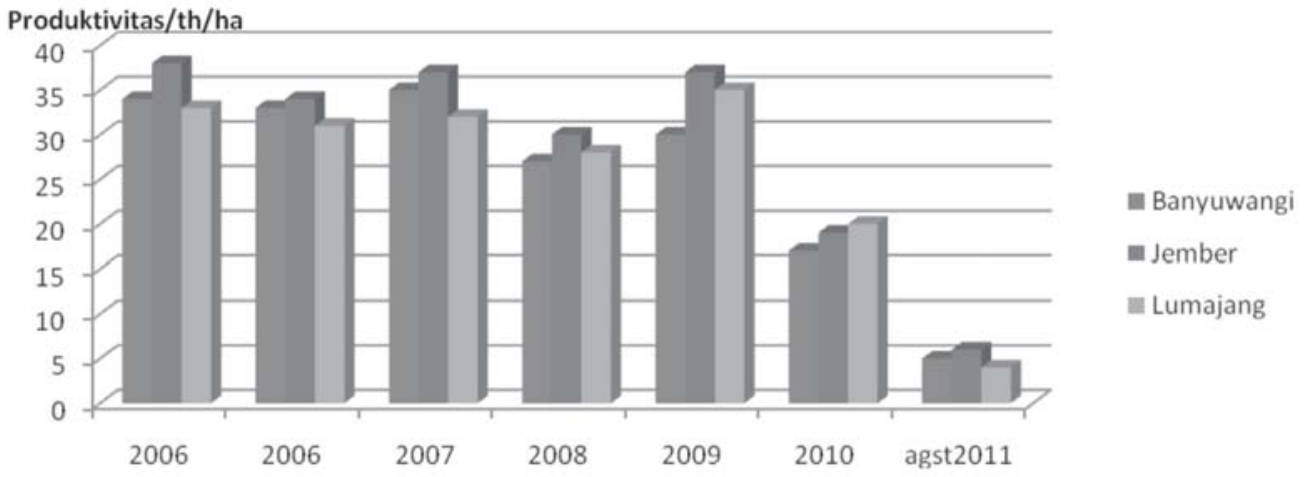

Gambar3. Produktivitas Jeruk Siam di Kabupaten Banyuwangi, Jember dan Lumajang Mulai tahun 2006 sampai Agustus 2011

Namun pada tahun 2011 kembali normal (terjadi musim kemarau).

Pengaruh Iklim Curah Hujan/Ketersediaan Air pada Fenologi

Pada tanaman jeruk siam, induksi pembungaan dapat terjadi setelah periode tersedianya air (Hodson, 1968 dalam Southwich and Davenport, 1987). Hasil penelitianya menunjukkan bahwa cekaman air selama 4-5 minggu dapat menghasilkan persentase tunas dan bunga tertinggi dibandingkan dengan pemakaian GA3 maupun perangsangan pembungaan melalui pangkasan. Penelitian Djoemaijah dkk (1996), pembungaan dan pembuahan jeruk keprok siam, dapat diatur melalui pengelolaan pemberian air yaitu dengan mengeringkan tanaman selama 2-6 minggu. Hal ini sama dengan penelitian Goldschmidt et al., 1972).

Akibat perubahan iklim ekstrim curah hujan terhadap fenologi tanaman jeruk adalah sebagai berikut. (lihat gambar 2)

Dari gambar 2 diketahui bahwa secara umum (tahun 2005 -2009) jeruk siam mengalami fase pembungaan sebanyak 2 sampai 3 kali setahun (Christian Junget al.,2009). Pada tahun 2010 terjadi peningkatan frekuensi pembungaan menjadi 5 sampai 6 kali setahun, namun dari bunga ini sedikit sekali yang menjadi buah 
(mengalami kerontokan/jundrop). Kerontokan ini dikarenakan tingginya curah hujan yang berakibat meningkatnya kandungan air tanah dan pada tanaman tidak terjadi metabolisme pembentukan buah yang optimal (Soutwich and Davenport, 1987). Curah hujan yang tinggi juga mengakibatkan perubahan temperatur udara. Temperatur udara sangat berperan terhadap aktivasi energi maupun inaktivasi enzim pembentukan buah jeruk (Nobuhito et. al., 2008). Risetnya menyebutkan Temperatur yang terlalu tinggi akan menurunkan cadangan makanan serta kandungan vitamin. Sebaliknya temperatur yang rendah mempengaruhi pewarnaan dan kerusakan buah. Intensitas cahaya. yang tinggi akan meningkatkan vitamin C, B1 dan kandungan beta karotin pada buah. Intensitas cahaya sepanjang fase pematangan pada buah juga berpengaruh terhadap proses pewarnaan buah.

Pengaruh Iklim Curah Hujan/Ketersediaan Air pada Produktivitas Jeruk Siam

Efek dari rendahnya tingkat bunga yang menjadi buah berakibat rendahnya produktivitas jeruk sebagai berikut (Gambar 3).

Dari gambar 3 terlihat produktivitas jeruk tahun 2006 sampai 2009 berkisar 28 sampai 38 ton/ha. Mukhopadhyay (2004) mengatakan secara normal produktifitas jeruk tangerin (siam) bisa mencapai lebih 40 ton/ha. Namun mulai 2010 terjadi penurunan produksi menjadi 16 sampai 18 ton/ha. Puncaknya terjadi penurunan drastis produksi jeruk pada 2011 hanya berproduksi 5-10 ton/ha. Hal ini kurang menguntungkan petani jeruk karena biaya produksi BEP minimal Rp. 31.682.861 (Supriyanto dkk., 2007) atau panen minimal 10 ton/ha (harga di petani tahun 2010 yaitu Rp 3000,-).
Riset Djoemaijah dkk. (1996) tentang pembungaan menyatakan bahwa banyaknya bunga berpengaruh pada prosentase buah jadi, semakin banyak bunga (batas maksimal) semakin tinggi peluang jadi buah. Namun hasil pengkajian menunjukkan walaupun frekuensi fenologi pada tahun 2010 akibat curah hujan tinggi meningkat dari biasanya tiga menjadi enam ternyata yang jadi buah sedikit. Hal ini dikarenakan curah hujan yang terus-menerus menyebabkan kelembapan dan kandungan air tanah yang tinggi sehingga kandungan air yang menuju ke bunga kelebihan dan menyebabkan kerontokan. Berdasarkan riset Harjadi (1982), pada tanaman yang sedang tumbuh aktif, proses fenologi membutuhkan air yang cukup banyak sehingga dengan adanya pengeringan, proses pembentukan koloid-koloid hidrofilik akan dipercepat dan selanjutnya mendorong perkembangan kuncup-kuncup bunga, buah dan biji.

Dampak dari curah hujan tinggi mengakibatkan banyak terjadi busuk akar akibat serangan Phitopthora sp. Dilaporkan sekitar 2030\% tanaman mati karena busuk akar (Dinas Pertanian 2010, Unpublished). Dengan adanya curah hujan yang tinggi dan terus-menerus mengakibatkan lembabnya tanah yang menyuburkan perkembangan jamur busuk akar (Phithopthora sp). Faktor penyebab serangan busuk akar lainya adalah rentannya batang bawah jeruk yaitu varietas Javanise citrum (Takhara et. al., 1994). Diluar negeri (Australia, AS dan Eropa sudah mengganti batang bawah yang tahan terhadap serangan jamur busuk akar salah satunya adalah varietas Citrumelo, Trifoliata dll, namun di Indonesia tidak populer karena tumbuhnya kerdil (Supriyanto dkk., 2007). 
Pengaruh Iklim Curah Hujan/ Ketersediaan Air pada Kualitas Jeruk Siam

Hasil penelitian Sri Puji (2009), tentang pengaruh iklim terhadap jeruk keprok di Tawangmangu, menunjukkan bahwa di daerah yang beriklim berbeda akan menghasilkan kualitas jeruk yang berbeda. Akibat curah hujan tinggi jeruk siam Kab. Jember mengalami penurunan kualitas dengan rasa kurang enak dan kurang manis dan mempunyai kandungan juice dan kadar air yang kurang. Sebelumnya Supriyanto dkk., (2007) meneliti total briks jeruk jember dengan total padatan terlarut sebesar 10 sampai 11, pada tahun 2010 dan 2011 turun menjadi 8 sampai 9. Hal ini disebabkan karena kandungan air dalam buah jeruk yang tinggi (ditandai dengan banyaknya pecah buah jeruk menjelang pasca jundrop) (Visser et. al., 1971)

\section{Rekomendasi}

Hasil pengkajian kebun jeruk petani yang menerapkan sistem PTKJS (pengelolaan terpadu kebun jeruk sehat) hasil pendampingan Balitjestro lebih berhasil mensiasati perubahan iklim ekstrim yaitu panen 10-12 ton/ha dengan kondisi tanaman lebih bagus. Sedangkan petani sendiri juga menerapkan beberapa cara seperti pembuatan parit-parit yang dalam $(50-100 \mathrm{~cm})$ agar tanaman jeruk ini tidak tergenang, namun efeknya tidak terlalu signifikan dan bahkan pada tahun 2011 ini terancam kesulitan pengairan sehingga petani kembali menutup parit-parit tersebut.
Kebun petani yang tidak menerapkan PTKJS
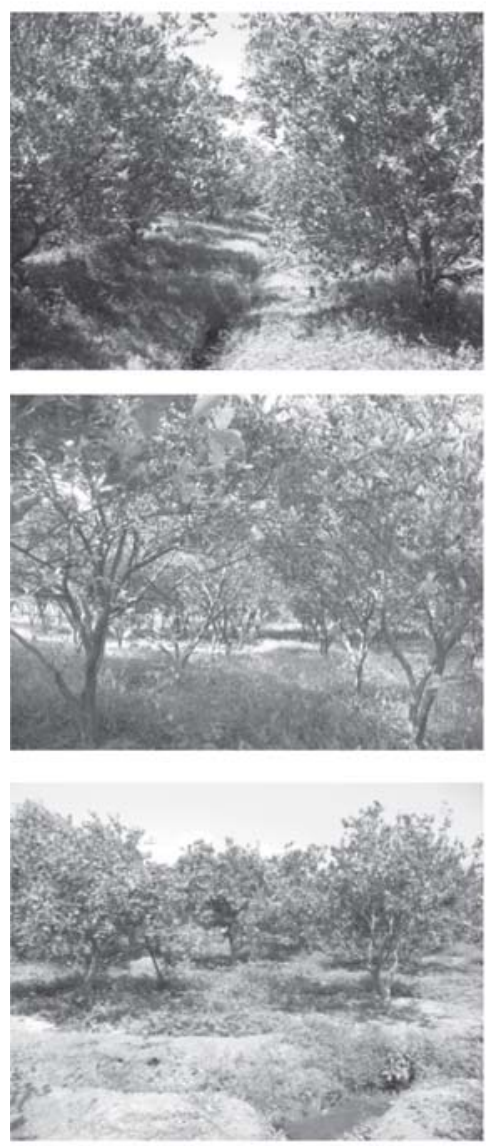

Gambar 4. Perbandingan Kebun Petani yang Menerapkan PTKJS dengan yang tidak Menerapkan PTKJS

Berikut ini perbandingan kebun petani yang menerapkan PTKJS dengan yang tidak menerapkan PTKJS. (Gambar 4)

Dari gambar 4. Dapat diketahui bahwa kebun petani yang menerapkan PTKJS jauh lebih baik pertumbuhan, kesehatan tanaman dan produktifitas dibanding kebun tanpa penerapan PTKJS. Voonet.al. (1992) menyatakan untuk memperoleh produktivfitas jeruk yang optimal hendaknya kebun dikelola secara modern salah satunya dengan bibit yang unggul dan pngelolaan kebun yang tepat. Secara sederhana PTKJS menyangkut 5 prinsip yaitu 1). penggunaan bibit jeruk bebas penyakit, 2).

Pengendalian hama penular penyakit CVPD, 3). 
Sanitasi kebun, 4). Pemeliharaan tanaman. 5. Konsolidasi pengelolaan kebun (Balitjestro 2007).

Dari hasil pengkajian ini diperoleh potensi daerah baru untuk budidaya jeruk siam yaitu lahan kering/tegalan dan tanah berpasir yang semula jeruk ditanam di lahan sawah. Di Jawa Timur potensi lahan kering dan tegalan sekitar 1.433 .000 ha yang pengelolaanya kurang optimal (tadah hujan) atau hanya ditanami tanaman tebu.

\section{SIMPULAN}

Dari hasil pembahasan dapat disimpulkan bahwa terjadi curah hujan tinggi (ekstrim) sepanjang tahun 2010 (musim kemarau tidak terjadi), terjadi kekacauan fenologi yang sebelumnya tanaman jeruk berbunga 1 sampai 3 kali setahun menjadi 4 sampai 6 kali setahun namun bunga ini tidak menjadi buah (terjadi kerontokan pentil buah/jundrop) dan berakibat kegagalan panen jeruk pada 2010 dan 2011. Produktivitas menurun drastis hingga tinggal 2540\% (5-10 ton/ha yang sebelumnya 20-30 ton/ ha) dengan kualitas (warna, rasa dan total total padatan terlarut) menurun. Didapatkan potensi baru yang baik untuk budidaya jeruk siam yaitu lahan kering/tegalan dan tanah berpasir yang semula jeruk ditanam di lahan sawah.

\section{DAFTAR PUSTAKA}

BALITJESTRO. 2007. Leflet Penerapan PTKJS (pengelolaan terpadu kebun jeruk bebas penyakit

Bureau of Meteorology Australian Goverment. 2012. RecordBreaking La Nina Events. Bureau of Meteorology. www.bom.gov.au. Diakses pada 18 Maret 2010

Djoemaijah dkk, 1996. Pengaruh Lama Pengeringan terhadap Pembungaan dan Pembuahan Jeruk Keprok Siam. Jurnal Horticultura 6(2):156-160.

Goldschmidt, E.E. and S.P. Monselise. 1972. Hormonal control of flowering in citrus and some other woody perennials, p.756766. In D.J. Carr (ed.). Plant Growth Substances 1970. SpringerVerlag, Berlin

Harjadi, S.S. 1982. Pengantar Agronomi. PT. Gramedia Jakarta
Hari, W. 2004. Agribisnis Jeruk di kabupaten Jember, Jawa Timur. Prosiding Seminar Jeruk Siam Nasional 2004. 87-101

Mukhopadhyay, S. 2004. Citrus: Production, Postharvest, Disease and Pest Management. Science Publishers, Inc. USA

Nobuhito M., Ryoji M., Terutaka Y., and Takeshi K. 2008. Citrus hybrid seedlings reduce initial time to flower when grafted onto shiikuwasha rootstock. Scientia Horticulturae 116:452455

Southwich, S.M and T.L Davenport. 1987. Modification of water stress-induced floral response in Tahiti Lime. Tropical Research and Education Center IFAS, University of Florida. J Amer, Soc. Hort. Sci. 112(2): 231-236

Sri Puji Rahayu, 2009; Prospek dan arah Pengembangan Agribisnis Jeruk. Jurnal Tanah dan Iklim, BB Litbang Sumberdaya Lahan Pertanian, Bogor

Supriyanto, A, Aprilia, S dan Lizia Z. 2007. Indikasi Tumbuhnya Supply Chain management (SCM) Jeruk di kabupaten Jember. Prosiding Seminar Nasional Jeruk 2007.

Voon, C.H., N. Hongsbhanich, C. Pitakpaivan, and A.J. Rowley. 1992. Cultar development in tropical fruits- An overview. Acta Hort., 321:270-28 